\title{
In-Stent Restenosis Indicator
}

National Cancer Institute

\section{Source}

National Cancer Institute. In-Stent Restenosis Indicator. NCI Thesaurus. Code C116148.

An indication as to whether there is re-narrowing of a stent implanted at a lesion site to treat a prior stenosis, to a diameter stenosis of greater than $50 \%$ within the stent. 